\title{
Regulation of Drosophila FMRFamide Neuropeptide Gene Expression
}

\author{
R. Nichols, ${ }^{1}$ J. McCormick, ${ }^{2}$ I. Lim ${ }^{3}$ \\ ${ }^{1}$ Department of Biological Chemistry, 830 N. University St., University of Michigan, Ann Arbor, \\ Michigan 48109-1048 \\ ${ }^{2}$ Department of Biology, University of Michigan, Ann Arbor, Michigan 48109-1048 \\ ${ }^{3}$ Undergraduate Honors Program, University of Michigan, Ann Arbor, Michigan 48109-1048
}

Received 22 September 1998; accepted 14 December 1998

\begin{abstract}
Physiologically important peptides are often encoded in precursors that contain several gene products; thus, regulation of expression of polypeptide proteins is crucial to transduction pathways. Differential processing of precursors by cell- or tissue-specific proteolytic enzymes can yield messengers with diverse distributions and dissimilar activities. FMRFamide-related peptides (FaRPs) are present throughout the animal kingdom and affect both neural and gastrointestinal functions. Organisms have several genes encoding numerous FaRPs with a common C-terminal structure but different $\mathrm{N}$-terminal amino acid extensions. We have isolated SDNFMRFamide, DPKQDFMRFamide, and TPAEDFMRFamide contained in the Drosophila FMRFamide gene. To investigate the regulation of expression of FMRFamide peptides, we generated antisera to distinguish among the three neuropeptides. We have previously reported the distribution of SDNFMRFamide and DPKQDFMRFamide. In this article, we describe TPAEDFMRFamide expression. TPAEDFMRFamide
\end{abstract}

antisera stain cells in embryonic, larval, pupal, and adult thoracic and abdominal ganglia. In addition, TPAEDFMRFamide-immunoreactive material is present in a lateral protocerebrum cell in adult. Thus, TPAEDFMRFamide antisera staining of neural tissue is different from SDNFMRFamide or DPKQDFMRFamide. In addition, TPAEDFMRFamide antisera stain larval, pupal, and adult gut, while SDNFMRFamide and DPKQDFMRFamide do not. TPAEDFMRFamide immunoreactivity is present in cells stained by FMRFamide antisera. Taken together, these data support the conclusion that TPAEDFMRFamide is differentially processed from the FMRFamide polypeptide protein precursor and may act in both neural and gastrointestinal tissue. () 1999 John Wiley \& Sons, Inc. J Neurobiol 39: 347-358, 1999

Keywords: brain-gut peptide; differential processing; double-label immunofluorescence; Drosophila; multiple antigenic peptide
Peptides play roles in many critical biological functions; thus, it is crucial to decipher regulation of peptide expression and signaling. Bioactive peptides are frequently present in precursors that contain multiple structurally related gene products and homologs

Correspondence to: R. Nichols

Contract grant sponsor: NSF; contract grant number: IBN 9724141

(C) 1999 John Wiley \& Sons, Inc. CCC 0022-3034/99/030347-12 of neuropeptides often exist in gastrointestinal tissue. Establishing the distribution of physiologically relevant messengers provides insight into regulation of gene expression and peptide activity.

One family of peptides has a common C-terminal FMRFamide but distinct $\mathrm{N}$-terminal extension. It is thought that the C-terminus is essential for binding, while the unique residues of a peptide confer differences in activity (Raffa, 1988). FMRFamide, isolated as a cardioexcitatory peptide (Greenberg and Price, 
1977), has been shown to elicit a wide variety of responses (Weiss et al., 1984; Robb et al., 1989; Day et al., 1994; Franks et al., 1994; Wang and Orchard, 1995). In addition, FMRFamide antisera have been used to identify immunoreactive materials and isolate peptides from numerous organisms (Dockray et al., 1983; Yang et al., 1985; Nichols, 1992a,b; Lange et al., 1994; Voronezhskaya and Elekes, 1996; Witten and Truman, 1996; Armstrong et al., 1997). The conservation of structure, function, spatial and temporal distribution, and abundance of FMRFamide peptides suggests that they play important roles in animal physiology.

Typically, organisms have more than one gene encoding multiple FMRFamide peptides (Nambu et al., 1988; Nichols et al., 1988; Marks et al., 1997). There is evidence for alternative splicing to produce different FMRFamide transcripts and products (Saunders et al., 1992; Bright et al., 1993; Santama et al., 1995; Price et al., 1997), and differential posttranslational processing of FMRFamide polypeptide precursors results in cell-specific expression patterns (Santama et al., 1993; Nichols et al., 1995a,b; Santama et al., 1997). The complexity of processing that FMRFamide precursors undergo provides an animal with a diverse array of gene products to affect a variety of physiological parameters.

We are studying the expression and processing of FMRFamide-containing gene products in Drosophila melanogaster (Nichols et al., 1988, 1995a,b; Nichols, 1992a,b, 1997; McCormick and Nichols, 1993; Nichols and Lim, 1996). Three Drosophila genes, dromyosuppressin (Dms) (Nichols, 1992a), drosulfakinin (Dsk) (Nichols et al., 1988), and FMRFamide (Nambu et al., 1988; Schneider and Taghert, 1988), encode numerous FMRFamide peptides. We have isolated DPKQDFMRFamide, SDNFMRFamide, and TPAEDFMRFamide (Nichols, 1992a,b) from the Drosophila FMRFamide gene.

Antisera to FMRFamide have been used to identify peptides in the Drosophila central nervous system (White et al., 1986; Chin et al., 1991; O'Brien et al., 1991; Schneider et al., 1991). While informative, these data are difficult to interpret because FMRFamide antisera do not distinguish among the numerous structurally related peptides. In addition, antisera to the FMRFamide precursor do not provide information on the distribution of individual FMRFamide peptides processed from the gene (Schneider et al., 1993).

Here, we present TPAEDFMRFamide expression. TPAEDFMRFamide immunoreactivity is present in the central nervous system and midgut at all stages of development. Although TPAEDFMRFamide-immu- noreactive material is present in cells stained by FMRFamide antisera, it is not colocalized with DPKQDFMRFamide (Nichols et al., 1995a) or SDNFMRFamide (Nichols et al., 1995b). In addition, the distribution of TPAEDFMRFamide is a subset of that described for the FMRFamide precursor (Schneider et al., 1993). These data support the conclusion that the Drosophila FMRFamide polypeptide protein precursor is differentially processed on a cellular level to yield unique distributions of structurally related peptides that may have diverse activities.

\section{MATERIALS AND METHODS}

\section{Antigen Design}

To generate antisera that would distinguish among the known Drosophila FMRFamide peptides and determine the expression of TPAEDFMRFamide, we raised antisera to TPAED-multiple antigenic peptide (MAP) (Postnett and Tam, 1989; Nichols et al., 1997). The five amino acid residues of the antigen represent the unique N-terminal extension of TPAEDFMRFamide and do not include the common FMRFamide C-terminal structure, thus avoiding the generation of antisera that would recognize FMRFamide or other Drosophila FMRFamide peptides. We chose to use an MAP antigen to maximize antigenicity and eliminate the need to conjugate the antigen to a carrier protein.

\section{Antisera Generation}

Antisera were raised in female New Zealand white rabbits as previously described (Nichols et al., 1995a,b). All protocols were approved by the University of Michigan Committee on Use and Care of Animals. Sera were assayed as previously described (White et al., 1986; McCormick and Nichols, 1993).

\section{Antisera Purification}

Crude antisera were purified on affinity column resin made by conjugating TPAED-MAP to Affi-gel 10 (BioRad Laboratories) according to the manufacturer's instructions, and equilibrated in $5 \times$ phosphate-buffered saline (PBS). The purification protocol was previously described (Nichols et al., 1995a,b; Nichols et al., 1997).

The specificity of the antisera was determined by designing the antigen to the N-terminal amino acid residues distinguishing TPAEDFMRFamide from FMRFamide and other Drosophila FMRFamide peptides. In addition, the method of purification selected for antisera recognizing TPAEDFMRFamide. Specificity was confirmed by preabsorbing the affinity-purified antisera with $10^{-4} M$ TPAEDMAP or FMRFamide prior to use in immunolocalization. We refer to the affinity-purified peptide-specific antisera as TPAEDFMRFamide antisera. 


\section{Animals}

Drosophila melanogaster Oregon $\mathrm{R}$ flies were maintained on cornmeal molasses media at $25^{\circ} \mathrm{C}$. At each developmental period, neural tissue was dissected from flies of a known age. Animals were collected for dissection based on the number of hours after egg laying for embryos, after hatching for larvae, after becoming white prepupae for pupae, and after eclosing for adults. Central nervous system tissue was dissected from 15- to 16-h embryos, 24-, 48-, 72-, and 96-h larvae, 24-, 48-, 72-, and 90-h pupae, and 3- and 7-day adults. Gastrointestinal tissue was dissected from wandering stage third-instar larvae, pupae, and 7-day adults. No difference in staining was observed between female and male flies.

\section{Immunolocalization}

Immunolocalization was performed as previously described (White et al., 1986; McCormick and Nichols, 1993; Nichols et al., 1995a,b). Briefly, tissue was dissected in $\mathrm{Ca}^{2+}$-free Ringer's solution $(130 \mathrm{mM} \mathrm{NaCl}, 4.7 \mathrm{mM} \mathrm{KCl}, 1.8 \mathrm{mM}$ $\mathrm{MgCl}_{2}, 0.74 \mathrm{mM} \mathrm{Na} \mathrm{HPO}_{4}$, pH 7) and fixed in $4 \%$ paraformaldehyde for $4-6 \mathrm{~h}$ at $4{ }^{\circ} \mathrm{C}$. After a thorough wash in PTN $\left[0.1 \mathrm{~m} M \mathrm{NaPO}_{4}, 0.3 \%\right.$ Triton X-100, 0.1\% NaAzide, $0.1 \%$ bovine serum albumin (BSA)], the tissue was incubated in primary antisera overnight at $4{ }^{\circ} \mathrm{C}$ with a slow rotatory motion, rinsed in PTN, and then placed in goat anti-rabbit Cy3-conjugated secondary antisera (Jackson ImmunoResearch Laboratories) for $4-6 \mathrm{~h}$ at $4^{\circ} \mathrm{C}$. After extensive washing in PTN, the tissue was rinsed in $4 \mathrm{~m} M$ NaCarbonate, $\mathrm{pH} 9$, before being mounted in $80 \%$ glycerol containing 5\% propyl gallate under a glass coverslip.

Double-label immunolocalization was performed as previously described (Nichols et al., 1995a,b). Rabbit antiFMRFamide (Peninsula Laboratories) was detected by fluorescein isothiocyanate (FITC)-labeled goat anti-rabbit second antibody (Sigma Chemical Corp.).

\section{Data Collection and Analysis}

Data were collected on a BioRad $600 \mathrm{Kr}$-Ar laser confocal attached to a Nikon inverted microscope using K1 and K2 filters and a $\times 20$ or $\times 40$ objective. Optical sections or $\mathrm{z}$ series were collected using the CoMos program. Adobe photoshop software, version 3.0, was used to process the data, and images were printed with a Kodak XLS8600 printer.

\section{RESULTS}

The terminology used to identify the cells stained by antisera is consistent with previous publications (White et al., 1986; Schneider et al., 1993). Immunoreactivity was observed bilaterally symmetric to the midline; thus, reference to one cell indicates the pres- ence of a pair of cells positioned bilaterally symmetric to one another. Signal intensity was strong and consistent, and eight or more preparations were analyzed for each experiment.

TPAEDFMRFamide immunoreactivity in embryonic neural tissue is shown in Figure 1. Staining was present in the nerve cord or ventral ganglion, a fused ganglion composed of three thoracic ganglia and eight abdominal ganglia. The antisera stained 11 cells near the midline of the embryonic ventral ganglion positioned anteriorly to posteriorly along the length of the ganglion in a row or chainlike formation. There was one cell in each of the three thoracic ganglia and a cell

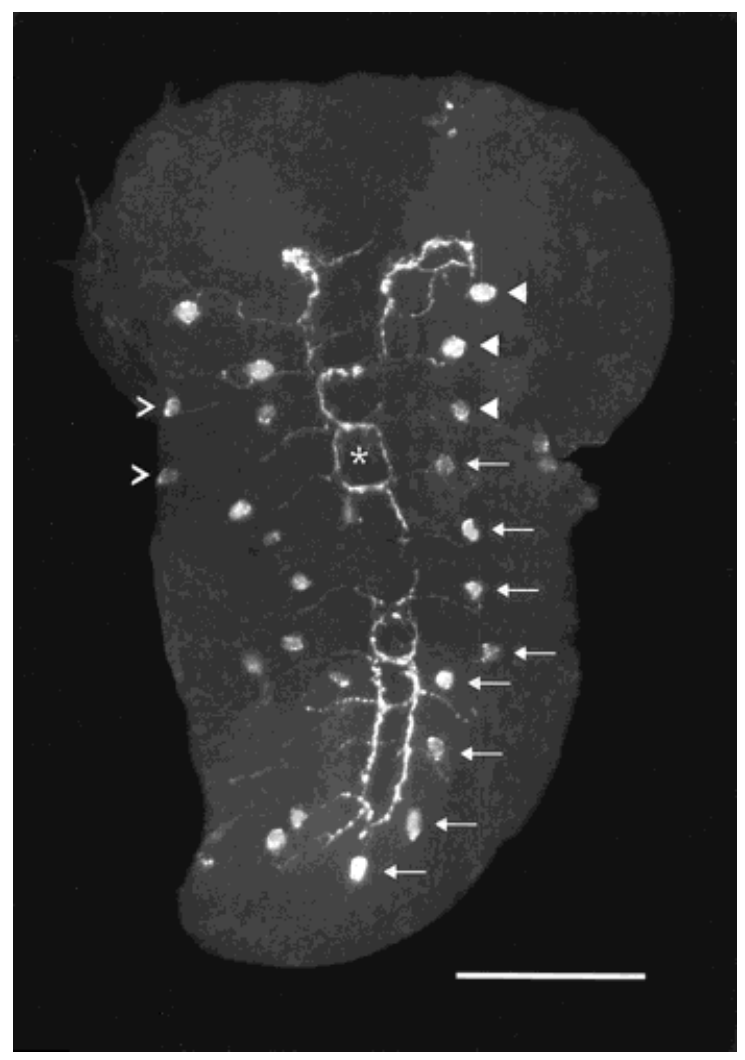

Figure 1 TPAEDFMRFamide-immunoreactive material in 15- to 16-h embryonic neural tissue. TPAEDFMRFamide immunoreactivity is present in 13 cells in the embryonic nerve cord at 15-16 h. Eleven cells (arrows and arrowheads) form a chain anteriorly to posteriorly along the midline of the ventral ganglion. The 11 cells consist of one cell in each of the three thoracic ganglia (arrowhead) and one per abdominal ganglion (arrow). Immunoreactive processes extend from these cells toward the midline and project anteriorly into the subesophageal ganglion. The processes also extend contralaterally across the midline forming commissure-like boxes (asterisk). Two additional cells (open arrowhead), positioned lateral to the chain of cells, one in the second thoracic ganglion, one in the third thoracic ganglion, are stained with antisera. Bar $=50 \mu \mathrm{m}$. 
per abdominal ganglion, thus accounting for the presence of 11 cells. There were two other immunoreactive cells positioned lateral relative to the chain. These cells, one in the second and one in the third thoracic ganglion, were located ventral relative to the row of cells in the thoracic and abdominal ganglia. An immunoreactive process extended from each stained thoracic and abdominal cell to the midline, where it turned and projected into the subesophageal ganglion. In addition to extending into the subesophageal ganglion, these immunoreactive fibers extended contralaterally across the ventral ganglion midline to form a series of commissure-like connectives or boxes.

The TPAEDFMRFamide antisera staining pattern observed in the first-instar larval central nervous system resembled that present in the embryonic ventral ganglion (Fig. 2). One noticeable difference between the staining in the embryo and the larva was that the processes along the midline of the ventral ganglion extended further into the brain and began to encircle the esophageal opening. In addition, the boxes made by the processes projecting from the ventral ganglion cells were more defined, forming what resembled a ladder along the length of the nerve cord midline. In third-instar larval neural tissue, the TPAEDFMRFamide-immunoreactive fibers that projected from the ventral ganglion cells completely surrounded the esophageal opening (Fig. 3). The cells in the nerve cord were intensely stained and there was an additional cell in the first thoracic ganglion that expressed TPAEDFMRFamide. With the staining of an additional cell in the first thoracic ganglion, each of the three thoracic ganglia contained two immunoreactive cells. Several cells in the subesophageal ganglion and brain lobes were detected with antisera although less intensely compared to the ventral ganglion cells. No processes appeared to extend from these subesophageal ganglion and brain lobe cells.

TPAEDFMRFamide-immunoreactive material was also expressed in the 24-h pupal central nervous system (Fig. 4). The cells stained by antisera in the pupal thoracic ganglion appeared to shift in position as a result, most likely, of morphological changes; however, the overall pattern and number of these cells remained constant. Also, at this time in development, the immunoreactive fibers that projected from the ventral ganglion cells to encircle the esophageal opening branched laterally projecting into the brain (Fig. 4). Compared to 24-h pupa, the arborization of these projections observed in 72-h pupa was increased with TPAEDFMRFamide-immunoreactive fibers extending through the brain into the optic lobes (Fig. 5). While faint signal was visible in cells near the esoph-

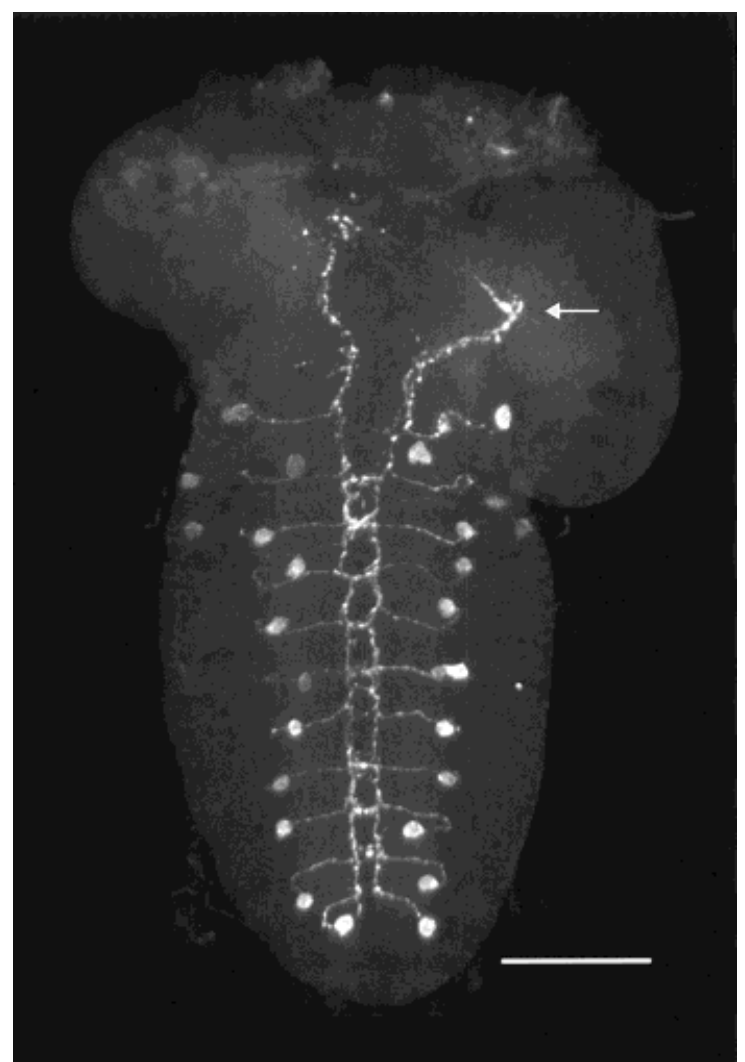

Figure 2 TPAEDFMRFamide-immunoreactive material in first-instar larval neural tissue. TPAEDFMRFamide immunoreactivity continues to be expressed in cells in the nerve cord and the processes extending from them. The number of cells expressing TPAEDFMRFamide is consistent from embryo to first-instar larva: one cell in the first thoracic ganglion, two in the second and third ganglia, and one per abdominal ganglia. However, the processes projecting from these cells begin to encircle to the esophageal opening (arrow) in the first-instar neural tissue more completely than seen in the embryo. Bar $=50 \mu \mathrm{m}$.

agus in 72-h pupa, the signal intensity in the ventral ganglion cells and processes remained unchanged.

In adult neural tissue, the number of immunoreactive cells present in the nerve cord decreased by one (Fig. 6). The thoracic and abdominal ganglia of the adult ventral ganglion contained 13 immunoreactive cells, with one thoracic ganglion cell no longer expressing TPAEDFMRFamide. There remained, however, one immunoreactive cell in the first thoracic ganglion, two cells in the second thoracic ganglion, two cells in the third thoracic ganglion, and one cell per abdominal ganglion that stained with antisera as seen in earlier stages of development. The processes from these cells maintained their signal intensity and contributed to the increased arborization in the ventral ganglion. The immunoreactive projections that origi- 


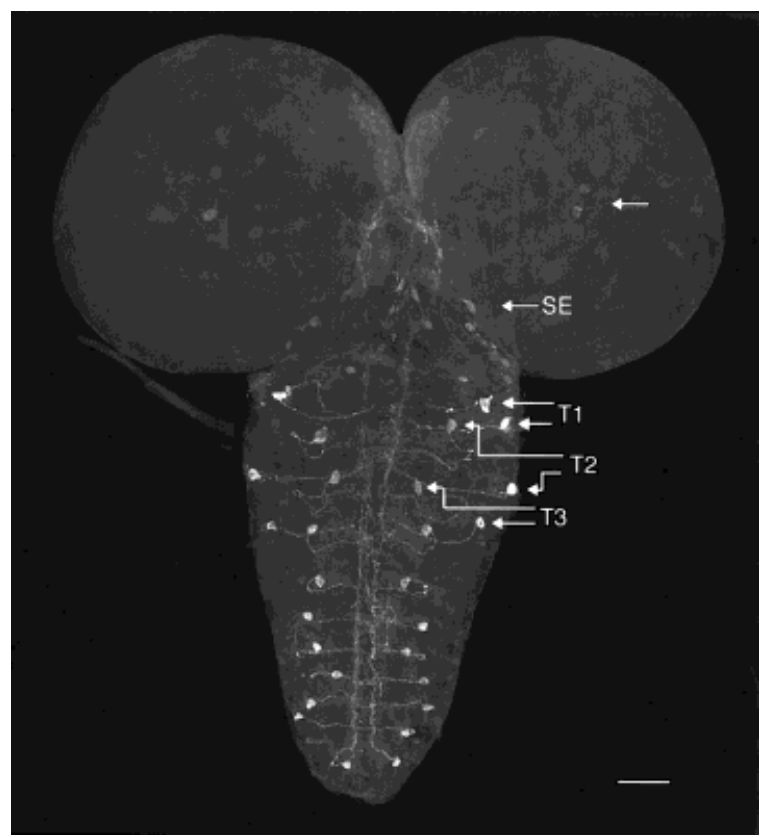

Figure 3 TPAEDFMRFamide-immunoreactive material in third-instar larval neural tissue. TPAEDFMRFamide distribution is present in cells of the nerve cord in the thirdinstar larva. There is an additional immunoreactive cell in the first thoracic ganglion. The two cells in the first thoracic ganglion are marked by arrows and T1, two cells in the second are indicated with arrows and $\mathrm{T} 2$, and the two cells in the third ganglion are shown with arrows and T3. Cells in the subesophageal ganglion (arrow and SE) and brain lobe (unlabeled arrow) are stained with TPAEDFMRFamide antisera. Bar $=50 \mu \mathrm{m}$.

nated from the nerve cord cells and encircled the esophageal opening were still present. There was an extensive increase in the complexity of the arborization of the immunoreactive fibers throughout the brain and the optic lobes. In addition, there was one cell in the adult lateral protocerebrum that stained with TPAEDFMRFamide antisera.

We observed TPAEDFMRFamide immunoreactivity in 12 cells in the larval anterior midgut (Fig. 7). No immunoreactive processes were associated with these cells. The signal intensity was moderate compared to the signal present in the ventral ganglion cells. Similarly, several cells in the pupal gut (data not shown) and in the adult anterior midgut also contained TPAEDFMRFamide-immunoreactive material (Fig. 8). No TPAEDFMRFamide immunoreactivity was observed in any other region of the gastrointestinal tract at any developmental period examined.

Double-label immunolocalization using TPAEDFMRFamide-specific antisera and FMRFamide antisera in the same tissue demonstrated that the TPAEDFMRFamide-immunoreactive ventral ganglion cells were a subset of cells containing FMRFamide-like material (Fig. 9). The same double-label immunolocalization protocol showed that the midgut cells stained by TPAEDFMRFamide antisera were a subset of cells containing FMRFamide immunoreactivity (Fig. 9).

\section{DISCUSSION}

Regulation of neuropeptide signaling is critical to physiology; hence, several modulatory mechanisms exist. One mode of regulation is at the posttranslational level with cell-specific proteolytic processing enzymes cleaving a polypeptide protein precursor to produce neuropeptides in unique expression patterns (Curry et al., 1991; LeBlanc et al., 1991; Brand et al., 1993; Mineo et al., 1995). Elucidating regulatory mechanisms involved in peptide expression is essential for understanding neurotransmission. The study of an abundant, diverse family of neuropeptides provides physiologically important information relevant to processing, structure-activity relationship, and function.

Three D. melanogaster genes, Dms, Dsk, and FM-

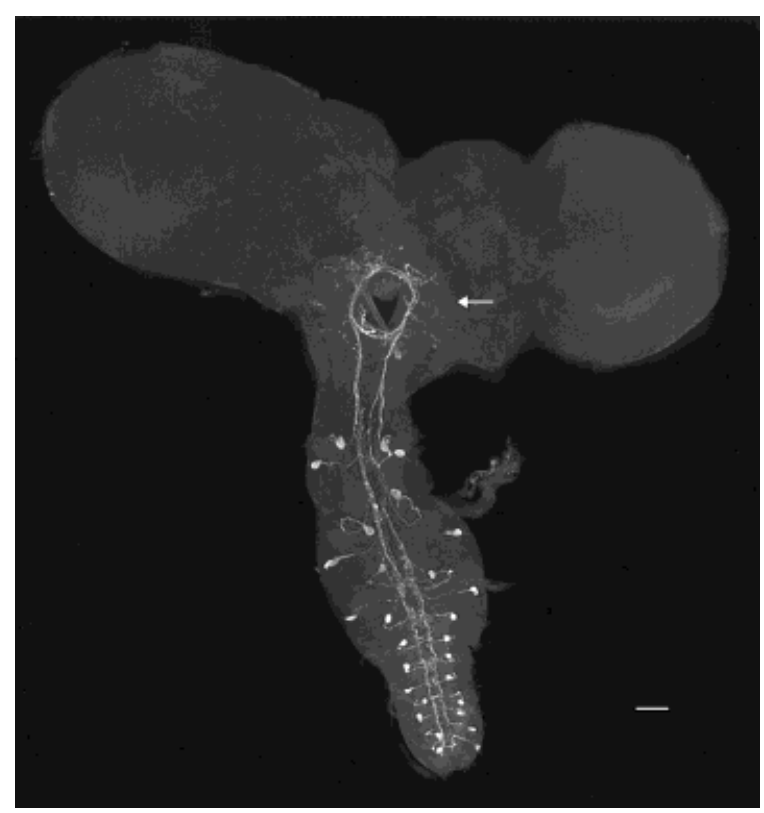

Figure 4 TPAEDFMRFamide-immunoreactive material in 24-h pupal neural tissue. TPAEDFMRFamide immunoreactivity continues to be expressed during metamorphosis. The distribution of the peptide in early pupal central nervous system is similar to that of third-instar larval neural tissue In the pupal central nervous system, however, the processes that extend from the ventral ganglion cells around the esophageal opening begin to arborize laterally into the brain lobes (arrow). Bar $=50 \mu \mathrm{m}$. 


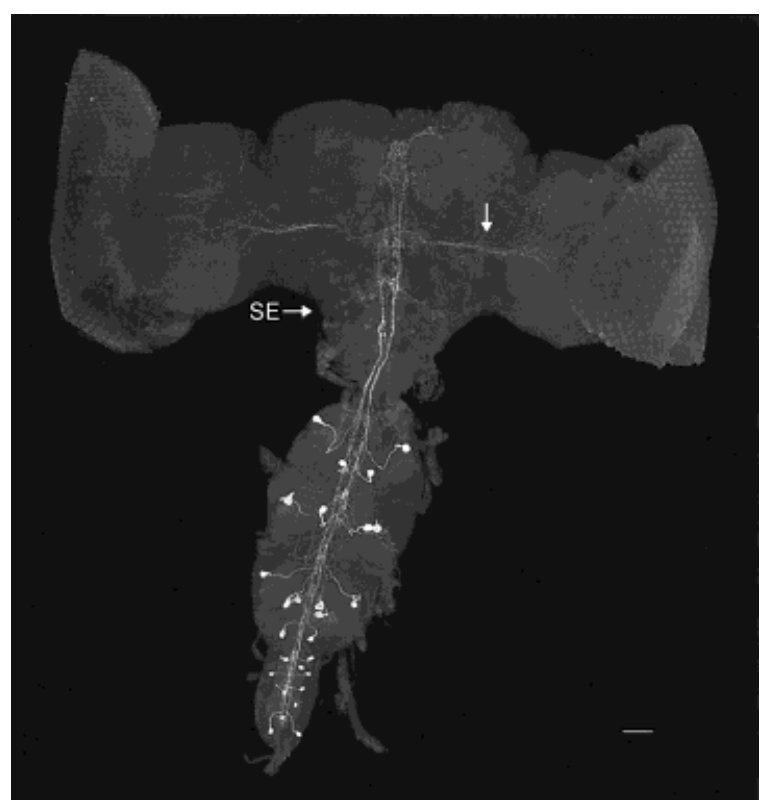

Figure 5 TPAEDFMRFamide-immunoreactive material in 72-h pupal neural tissue. TPAEDFMRFamide immunoreactivity in the ventral ganglion is not altered as the animal continues through metamorphosis. Several cells in the subesophageal ganglion are stained (arrow labeled SE). The immunoreactive processes that encircle the esophageal opening continue to extend laterally into the brain lobes (unlabeled arrow) and at the 72-h pupal stage have reached the optic lobes. Bar $=50 \mu \mathrm{m}$.

RFamide, are known to encode several structurally related FMRFamide peptides (Nambu et al., 1988; Nichols et al., 1988; Schneider and Taghert, 1988, McCormick et al., 1993). We have reported the isolation and structure analysis of three Drosophila FMRFamide peptides, DPKQDFMRFamide, SDNFMRFamide, and TPAEDFMRFamide (Nichols, 1992a,b). We raised antisera specific to DPKQDFMRFamide and SDNFMRFamide and determined their spatial and temporal distribution (Nichols et al., 1995a,b). The expression of TPAEDFMRFamide has not been described. To elucidate the distribution of TPAEDFMRFamide, we raised antisera to an antigen representing the unique $\mathrm{N}$-terminal extension of the peptide and performed whole-mount immunolocalization on both neural and gastrointestinal tissue.

A prominent feature of TPAEDFMRFamide expression at all stages of development was the staining of nerve cord cells and the immunoreactive fibers that extended from these cells and projected into the subesophageal ganglion (Figs. 1-6). The number and position of cells stained were constant and the signal was strong, suggesting that TPAEDFMRFamide plays an important role(s) throughout the life of the animal. The quantity and complexity of the immunoreactive ventral ganglion cells and associated projections implied that there may be several sources of input into the release of TPAEDFMRFamide and numerous sites of TPAEDFMRFamide action.

The appearance of processes around the esophageal opening during development implies that TPAEDFMRFamide has a role(s) relative to the function of the esophagus (Figs. 1-6). The origin of fibers suggests that there are multiple sources from which information can be derived to affect release at this site(s). Our method of dissecting neural tissue from surrounding and attached tissue does not allow us to track the TPAEDFMRFamide innervation to its full extent. However, we know from our analysis of gastrointestinal tissue that TPAEDFMRFamide-containing fibers do not terminate directly on the foregut. This does not preclude that the peptide is released from these nerve endings to act on other neurons that directly innervate the esophagus and/or gut.

Fibers extended into the subesophageal ganglion and brain, and projections from the thoracic and ab-

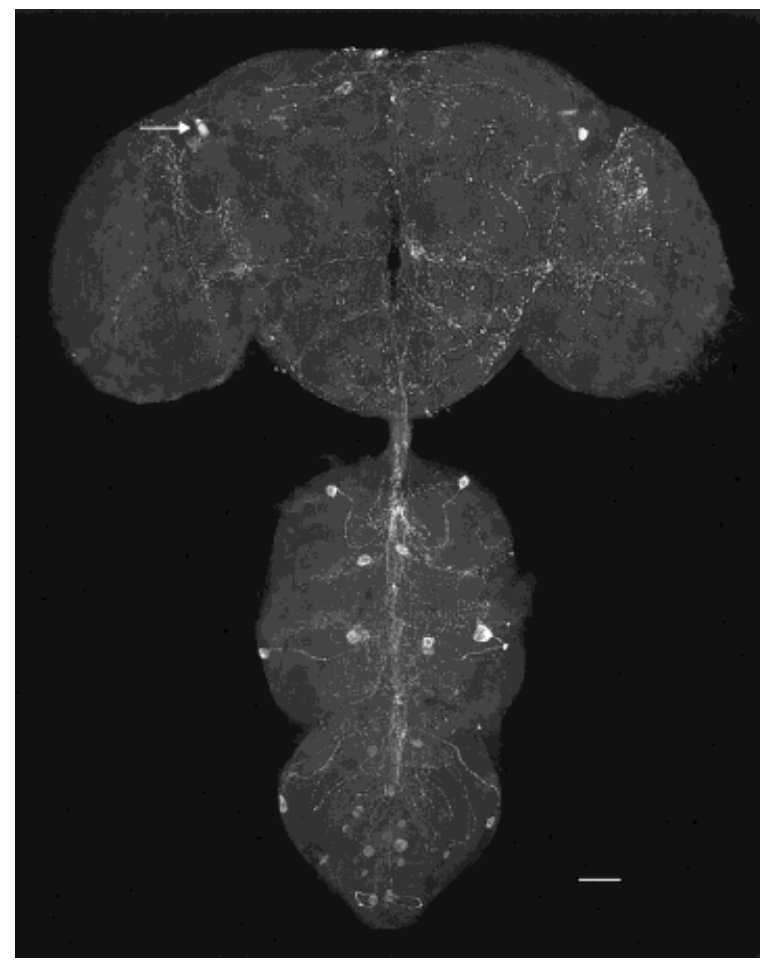

Figure 6 TPAEDFMRFamide-immunoreactive material in neural tissue from 3-day adult. TPAEDFMRFamide continues to be expressed in cells and processes in the adult ventral ganglion and brain. The brain and optic lobe immunoreactive processes have significantly increased in number and complexity. In addition, a lateral protocerebrum cell is stained intensely with TPAEDFMRFamide antisera (arrow). Bar $=50 \mu \mathrm{m}$. 

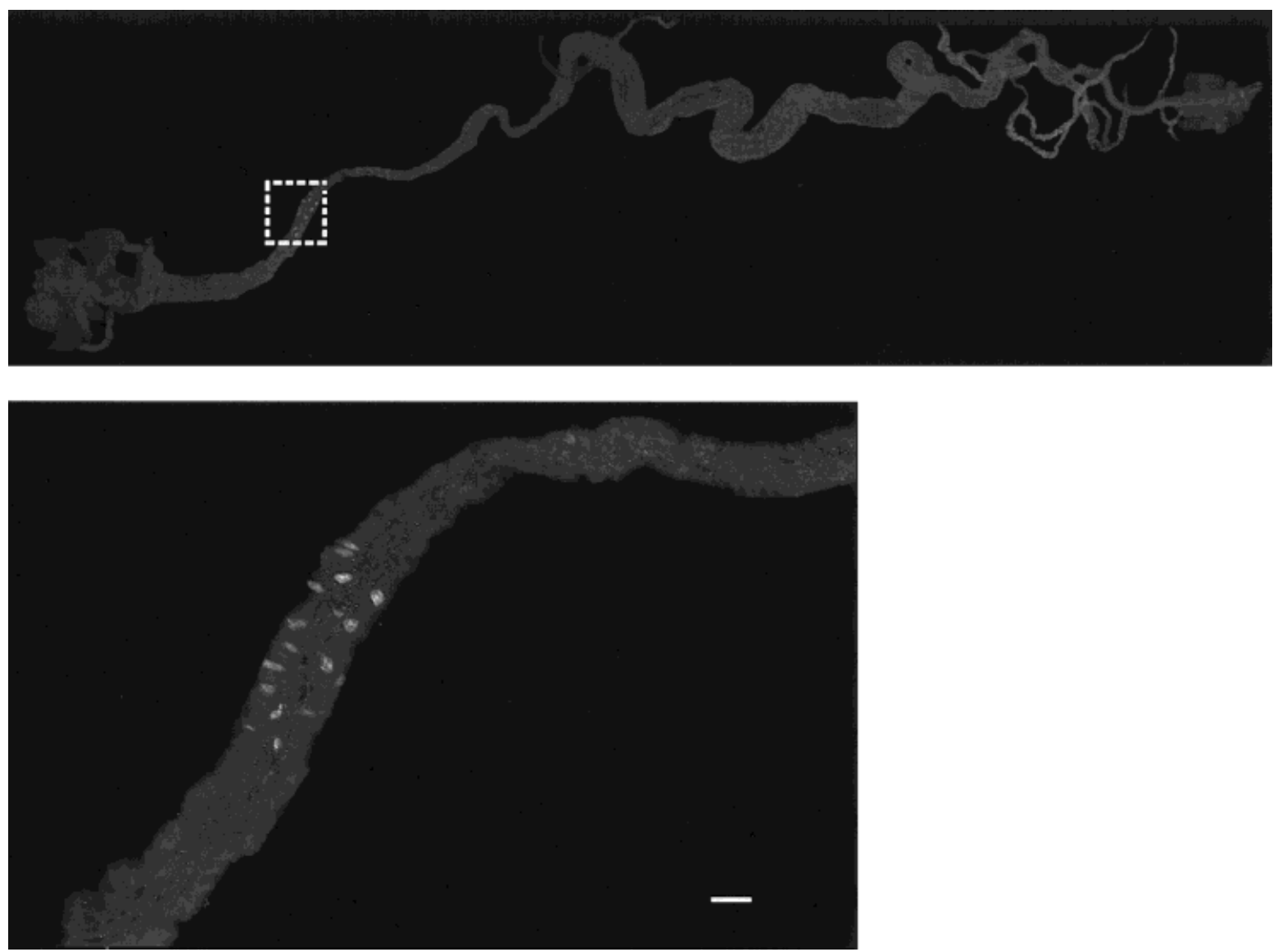

Figure 7 TPAEDFMRFamide-immunoreactive material in the third-instar larval gastrointestinal tract. TPAEDFMRFamide is present in 12 cells in the anterior midgut. No processes can be seen to extend from the cells. (Top) Whole larval gastrointestinal tract; left is anterior and right is the posterior. (Bottom) Enlargement of the region within the rectangle (top). It is the area of the midgut containing the cells expressing TPAEDFMRFamide-immunoreactive material. Bar $=50 \mu \mathrm{m}$.

dominal cells crossed the midline to form commissures to give the fasiculating neurites a ladderlike appearance along the length of the nerve cord that is present throughout development (Figs. 1-6). The continued presence of these projections stained with TPAEDFMRFamide antisera implies that this region may constitute an important peptidergic release site(s).

The immunoreactive processes at the midline of the ventral ganglion (Figs. 1-6) coincided with a neuronal sheath that has been described as one of two neurohemal release sites in Drosophila and the blowfly, Calliphora vomitoria (Raabe, 1989; Lundquist and Nässel, 1990; Nässel et al., 1994). It has been reported that subesophageal neurons in Calliphora send processes to this neurohemal region and release serotonin into the circulation at this site (Nässel and Elekes, 1985; Trimmer, 1985). This is notable because of the precedence for the interaction of FMRFamide peptides with serotonin (Brownlee et al.,
1995; Wurden and Homberg, 1995). Furthermore, consistent with this expression of TPAEDFMRFamide, FMRFamide-like materials are reported to have neurohormonal functions (Myers and Evans, 1985; Carroll et al., 1986; Jagdale and Gordon, 1994; Schoofs et al., 1997). In addition, FMRFamide-immunoreactive material has been observed to be released from peptidergic fibers of the Calliphora dorsal sheath (Nässel et al., 1994).

TPAEDFMRFamide immunoreactivity in the optic lobes (Figs. 4-6) implies that the peptide may play a role in phototransduction or associated neural functions. TPAEDFMRFamide staining is present in the lobula, an area in which there are a number of neurons that sense motion and direction relaying messages to the appropriate neural centers (Strausfeld, 1976, 1984; Mobbs, 1985). Thus, TPAEDFMRFamide may be involved in communicating some aspect of motion.

The TPAEDFMRFamide-immunoreactive adult lateral protocerebral cell (Fig. 6) is located in the 


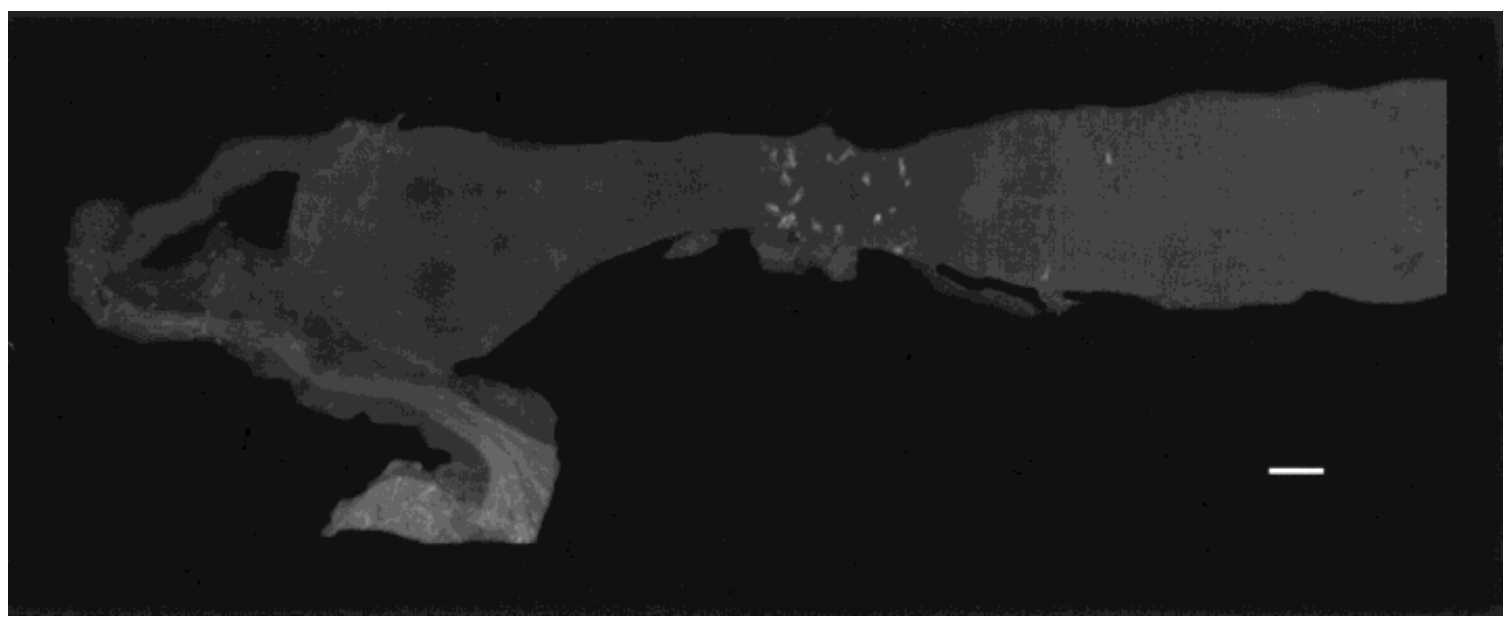

Figure 8 TPAEDFMRFamide immunoreactivity in the 3-day adult gastrointestinal tract. TPAEDFMRFamide immunoreactivity is present in several cells of the gastrointestinal tract in the adult anterior midgut. Bar $=50 \mu \mathrm{m}$.

region of the antennal lobe where sensory information detected by the antennae is processed (Mobbs, 1985). The appearance of signal in this cell in the adult, the stage when the antennae are functional, may indicate that TPAEDFMRFamide is involved in sensory stimuli signaling. This is in agreement with what is found in other organisms, where FMRFamide peptides act to relay sensory information in neural tissue as indicated by immunolocalization and electrophysiological data (Umino and Dowling, 1991; Cowden et al., 1993; Wikgren and Fagerholm, 1993; Xu et al., 1994).

The cells in the anterior midgut containing TPAEDFMRFamide immunoreactivity (Figs. 7 and 8 ) are present in the region of the gastrointestinal tract where digestion and absorption occur (Demerec, 1950). Peptidergic cells are present in this region of the midgut in Drosophila, Calliphora, and other insects (Zitnan et al., 1993, Nässel et al., 1994). Gut endocrine cells may function to perceive nutrient content and/or tension of the muscle wall (Fujita et al., 1988). The action of these cells is probably local and may affect gut movement, production of digestive enzymes, circulation in the digestive tissue, and/or epithelial shedding. The presence of TPAEDFMRFamide in the anterior midgut suggests that it may be involved in these gastrointestinal processes.

Since our antisera recognized the N-terminal amino acid residues of TPAEDFMRFamide and not the C-terminal FMRFamide, we performed double immunolabeling experiments to confirm that TPAEDFMRFamide antisera staining was coincident with FMRFamide-immunoreactive material. Our doublelabel immunolocalization with TPAEDFMRFamide antisera and FMRFamide antisera showed that the
TPAEDFMRFamide staining was a subset of FMRFamide immunoreactivity in both neural and gut tissues (Fig. 9). In neural tissue (Fig. 9, upper panel), FMRFamide-stained cells were labeled with secondary antisera conjugated to FITC (green), while the TPAEDFMRFamide-containing cells were labeled with a secondary antisera conjugated to Cy3 (red). Overlap of the green and red fluorescence signals produced yellow and demonstrated that TPAEDFMRFamide was expressed in a subset of cells also stained with FMRFamide antisera. In the gastrointestinal tract (Fig. 9, lower panel), TPAEDFMRFamide was present in cells also stained with FMRFamide antisera. Cy3-conjugated secondary antisera (red) recognized TPAEDFMRFamide antisera and FITC (green)labeled secondary antisera recognized FMRFamide antisera. Yellow fluorescence resulted when TPAEDFMRFamide antisera bound antigen in a subset of cells stained with FMRFamide antisera. Thus, it is likely that our peptide-specific TPAEDFMRFamide antisera recognized TPAEDFMRFamide and not a substance with a structurally similar N-terminus. This argument is also supported by the fact that the TPAEDFMRFamide expression pattern is contained within the distribution of the Drosophila FMRFamide transcript and precursor (O’Brien et al., 1991; Schneider et al., 1991, 1993).

Together with previous studies (Nichols et al., 1995a,b), these immunolocalization data indicate that the Drosophila FMRFamide gene products DPKQDFMRFamide, SDNFMRFamide, and TPAEDFMRFamide have unique spatial and temporal distributions (Fig. 10). DPKQDFMRFamide antisera stain cells in each of the three thoracic ganglia, one cell in the 

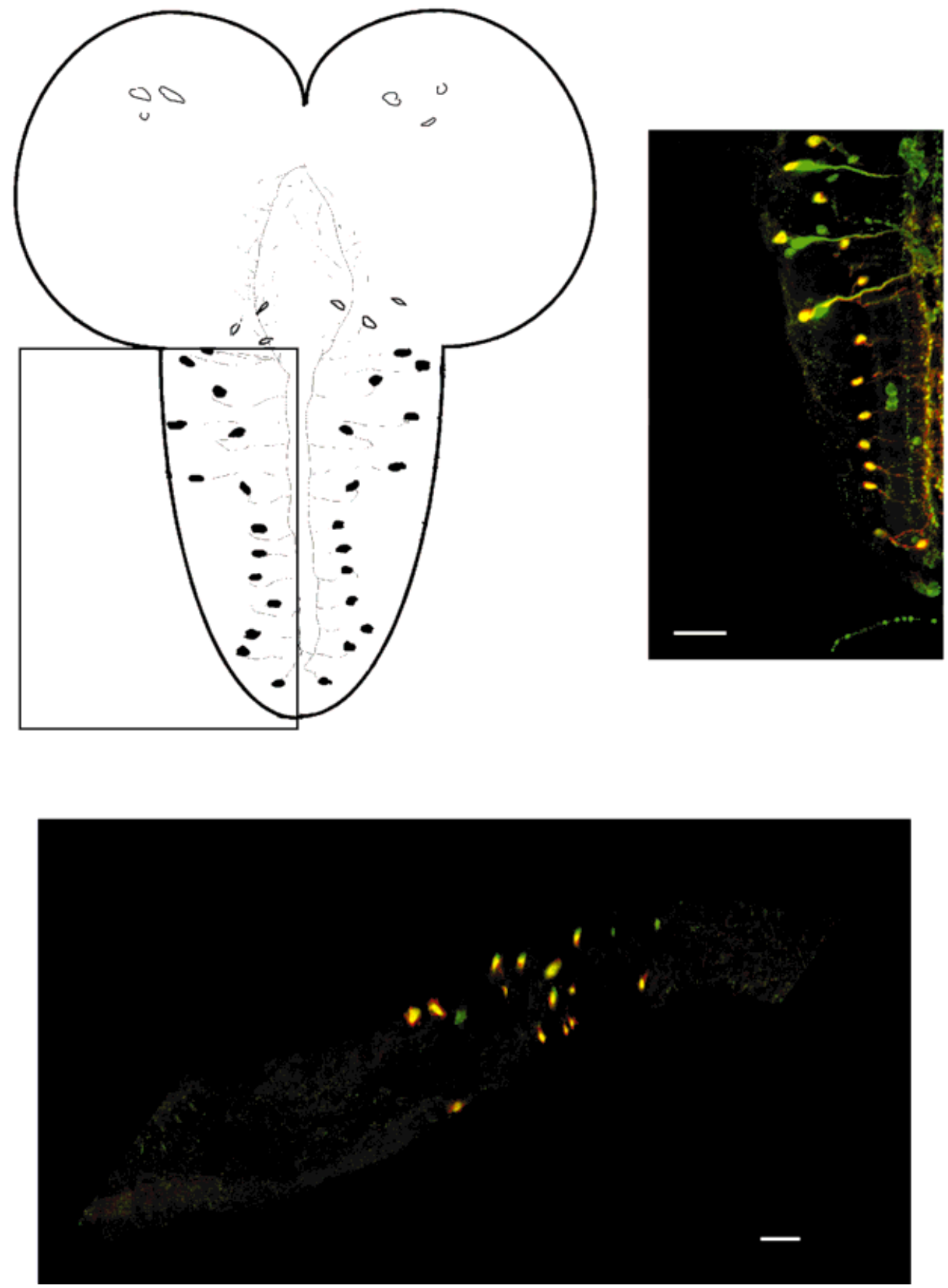

Figure 9 (Upper) TPAEDFMRFamide/FMRFamide third-instar larval neural tissue double-label immunofluorescence. TPAEDFMRFamide immunoreactivity is present in cells of the ventral ganglion stained with FMRFamide antisera. The schematic on the left depicts a larval central nervous system stained with TPAEDFMRFamide antisera. The boxed section of the ventral ganglion represents the immunofluorescence shown on the right. FMRFamide-stained cells are labeled with secondary antisera conjugated to FITC (green), while the TPAEDFMRFamidecontaining cells are labeled with a secondary antisera conjugated to Cy3 (red). The yellow signal demonstrates that TPAEDFMRFamide is expressed in a subset of cells also stained with FMRFamide antisera. (Lower) TPAEDFMRFamide/FMRFamide third-instar larval gastrointestinal tract double-label immunofluorescence. TPAEDFMRFamide immunoreactivity is present in cells of the anterior midgut that are stained with FMRFamide antisera. Cy3-conjugated secondary antisera (red) recognize TPAEDFMRFamide antisera and FITC (green)-labeled secondary antisera recognize FMRFamide antisera. The yellow fluorescence of the cells is a result of TPAEDFMRFamide antisera binding antigen in a subset of cells stained with FMRFamide antisera. Bar $=50 \mu \mathrm{m}$. 

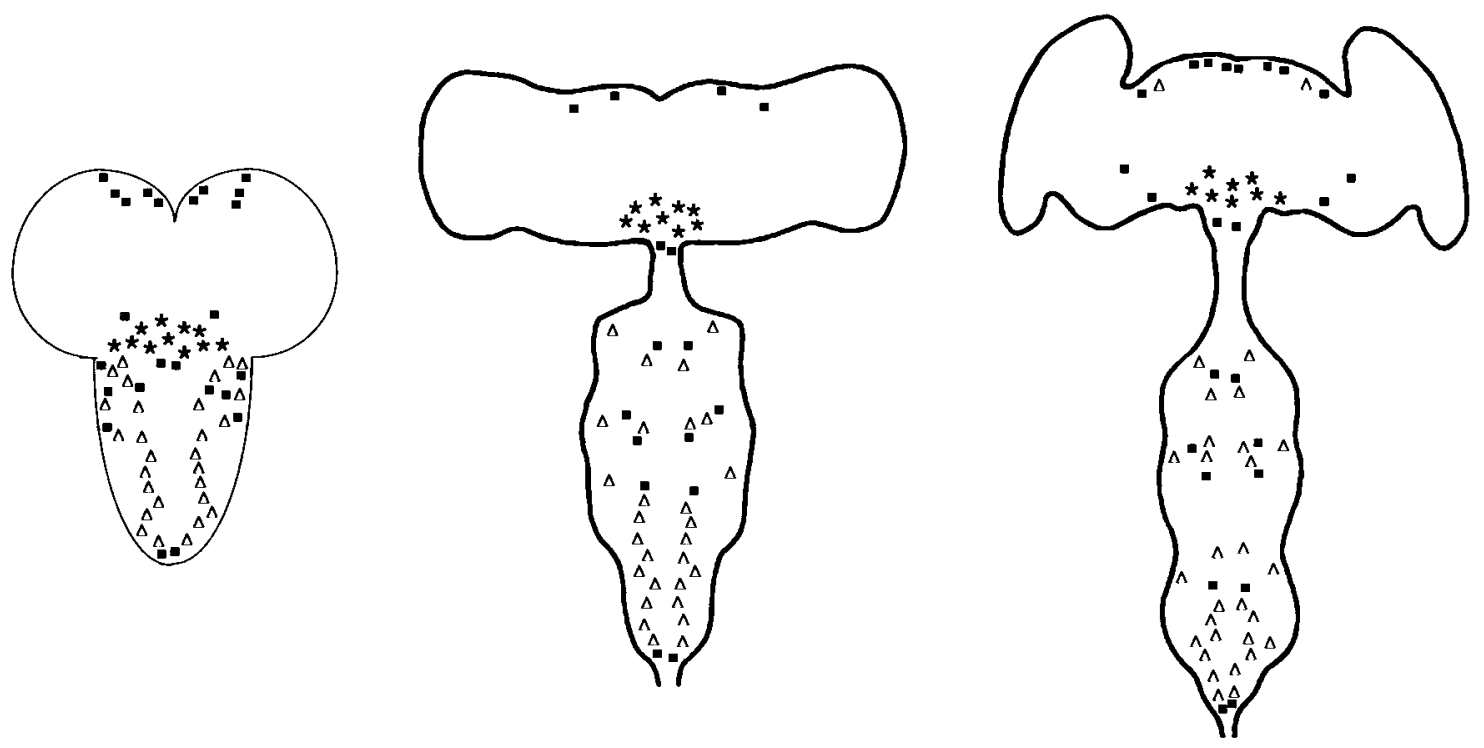

Figure 10 Drosophila FMRFamide peptide staining in the central nervous systems of larva (left),

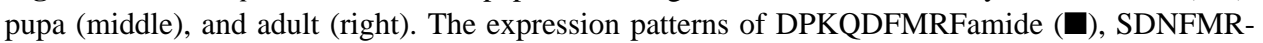
Famide $(*)$, and TPAEDFMRFamide-immunoreactive materials $(\triangleright)$ do not overlap in Drosophila neural tissue.

subesophageal ganglion, and several cells in the superior protocerebrum (Nichols et al., 1995a). The thoracic ganglia cells stained by DPKQDFMRFamide antisera are more dorsal than those stained by TPAEDFMRFamide (Nichols et al., 1995a). SDNFMRFamide immunoreactivity is present in several cells of the subesophageal ganglion, but is not present in the cells of the nerve cord (Nichols et al., 1995b). The patterns of expression of both DPKQDFMRFamide and SDNFMRFamide are subsets of FMRFamide antisera staining and are present in cells containing the FMRFamide polyprotein precursor (Nichols et al., 1995a,b).

TPAEDFMRFamide-immunoreactive material is expressed in the central nervous system and gastrointestinal tract in all stages of development, suggesting that the peptide has important roles in physiology. Double-immunolabeling data indicate that TPAEDFMRFamide antisera staining is a subset of FMRFamide immunoreactivity (Fig. 9) and TPAEDFMRFamide appears to be present in cells containing the FMRFamide precursor (Schneider et al., 1993). In addition, TPAEDFMRFamide-immunoreactive material does not coexist with DPKQDFMRFamide and SDNFMRFamide (Fig. 10) (Nichols et al., 1995a,b). These data support the conclusion that differential posttranslational processing of the Drosophila FMRFamide polypeptide precursor to produce unique cellular expression patterns is a means by which to regulate the distribution of structurally related peptides that may have diverse and different activities.

This study was supported by National Science Foundation Grant IBN 9724141 to RN.

\section{REFERENCES}

Armstrong EP, Halton DW, Tinsley RC, Cable J, Johnston RN, Johnston CF, Shaw C. 1997. Immunocytochemical evidence for the involvement of an FMRFamide-related peptide in egg production in the flatworm parasite Polystoma nearcticum. J Comp Neurol 377:41-48.

Brand SJ, Fuller PJ. 1993. Differential gastrin gene expression in rat gastrointestinal tract and pancreas during neonatal development. J Biol Chem 263:5341-5347.

Bright K, Kellett E, Saunders SE, Brierley M, Burke JF, Benjamin PR. 1993. Mutually exclusive expression of alternatively spliced FMRFamide transcripts in identified neuronal systems of the snail Lymnaea. J Neurosci 13: 2719-2729.

Brownlee DJ, Holden-Dye L, Fairweather I, Walker RJ. 1995. The action of serotonin and the nematode neuropeptide KSAYMRFamide on the pharyngeal muscle of the parasitic nematode, Ascaris suum. Parasitology 111: 379-384.

Carroll LS, Carrow GM, Calabrese RL. 1986. Localization and release of FMRFamide-like immunoreactivity in the cerebral neuroendocrine system of Manduca sexta. J Exp Biol 126:1-14. 
Chin AC, Reynolds ER, Scheller RH. 1990. Organization and expression of the Drosophila FMRFamide-related prohormone. DNA Cell Biol 9:263-271.

Cowden C, Sithigorngul P, Brackley P, Guastella J, Stretton AOW. 1993. Localization and differential expression of FMRFamide-like immunoreactivity in the nematode Ascaris suum. J Comp Neurol 333:455-468.

Curry WJ, Johnston CF, Hutton JC, Arden SD, Rutherford NG, Shaw C, Buchanan KD. 1991. The tissue distribution of rat chromogranin A-derived peptides: evidence for differential tissue processing from sequence specific antisera. Histochemistry 96:531-538.

Day TA, Maude AG, Shaw C, Halton DW, Moore S, Bennett SL, Pax RA. 1994. Platyhelminth FMRFamiderelated peptides (FaRPs) contract Schistosoma manson (Trematoda: Digenea) muscle fibers in vitro. Parasitology 109:455-460.

Demerec M. 1950. Biology of Drosophila. New York: Wiley.

Dockray GJ, Reeve JR, Shively J, Gayton RJ, Barnard CS. 1983. A novel active pentapeptide from chicken brain identified by antibodies to FMRFamide. Nature 305:328 330.

Franks CJ, Holden-Dye L, Williams RG, Pang FY, Walker RJ. 1994. A nematode FMRFamide-like peptide, SDPNDLRFamide (PF1), relaxes the dorsal muscle strip preparation of Ascaris suum. Parasitology 108:229-236.

Fujita T, Kanno T, Kobayashi S. 1988. The paraneuron. Heidelberg: Springer. 367 p.

Jagdale GB, Gordon R. 1994. Distribution of FMRF-amidelike peptide in the nervous system of a mermithid nematode, Romanomermis culicivorax. Parasitol Res 80:467473.

Lange AB, Peeff NM, Orchard I. 1994. Isolation, sequence, and bioactivity of FMRFamide-related peptides from locust ventral nerve cord. Peptides 15:1089-1094.

LeBlanc AC, Chen HY, Autilio-Gambetti L, Gambetti P. 1991. Differential APP gene expression in rat cerebral cortex, meninges, and primary astroglial, microglial, and neuronal cultures. FEBS Lett 292:171-178.

Lundquist T, Nässel DR. 1990. Substance P-, FMRFamide-, and gastrin/cholecystokinin-like immunoreactive neurons in the thoraco-abdominal ganglia of the flies Drosophila and Calliphora. J Comp Neurol 294:161-178.

Marks NJ, Maule AG, Geary TG, Thompson DP, Davis JP, Halton DW, Shaw C. 1997. APEASPFIRFamide, a novel FMRFamide-related decapeptide from Caenorhabditis elegans: structure and myoactivity. Biochem Biophys Res Commun 231:591-595.

McCormick J, Nichols R. 1993. Spatial and temporal expression identify dromyosuppressin as a brain-gut peptide in Drosophila melanogaster. J Comp Neurol 338:279288.

Mineo I, Matsumura T, Shingu R, Namba M, Kuwajima M, Matsuzawa Y. 1995. The role of prohormone convertases PC1 (PC3) and PC2 in the cell-specific processing of proglucagon. Biochem Biophys Res Commun 207:646651 .
Mobbs PG. 1985. Brain structure. In: Kerkut GA, Gilbert LI, editors. Comprehensive insect physiology, biochemistry, and pharmacology. Oxford: Pergamon Press. p 299-370.

Myers CM, Evans PD. 1985. The distribution of bovine pancreatic polypeptide/FMRFamide-like immunoreactivity in ventral nervous system of locust. J Comp Neurol 234:1-16.

Nambu JR, Murphy-Erdosh C, Andrews PC, Feistner GJ, Scheller RH. 1988. Isolation and characterization of a Drosophila neuropeptide gene. Neuron 1:55-61.

Nässel DR, Bayraktaroglu E, Dircksen H. 1994. Neuropeptides in neurosecretory and efferent neural systems of insect thoracic and abdominal ganglia. Zool Sci 11:1531.

Nässel DR, Elekes K. 1985. Serotonergic terminals in the neural sheath of the blowfly nervous system: ultrastructural immunocytochemistry and 5,7-dihydroxytryptamine labeling. Neuroscience 15:293-307.

Nichols R, Schneuwly SA, Dixon JE. 1988. Identification and characterization of a Drosophila homologue to the vertebrate neuropeptide cholecystokinin. J Biol Chem 263:12167-12170.

Nichols R. 1992a. Isolation and structural characterization of Drosophila TDVDHVFLRFamide and FMRFamidecontaining neural peptides. J Mol Neurosci 3:213-218.

Nichols R. 1992b. Isolation and expression of the Drosophila drosulfakinin neural peptide gene product, DSK-I. Mol Cell Neurosci 3:342-347.

Nichols R, McCormick J, Lim I, Caserta L. 1995a. Cellular expression of the Drosophila melanogaster FMRFamide neuropeptide gene product DPKQDFMRFamide. J Mol Neurosci 6:1-10.

Nichols R, McCormick J, Lim I, Starkman J. 1995b. Spatial and temporal analysis of the Drosophila FMRFamide neuropeptides gene product SDNFMRFamide: evidence for a restricted expression pattern. Neuropeptides 29: 205-213.

Nichols R, Lim I. 1996. Spatial and temporal immunocytochemical analysis of drosulfakinin (Dsk) gene products in the Drosophila melanogaster central nervous system. Cell Tissue Res 283:107-116.

Nichols R, McCormick J, Lim I. 1997. Multiple antigenic peptides designed to structurally-related Drosophila peptides. Peptides 18:41-45.

O'Brien MA, Schneider LE, Taghert PH. 1991. In situ hybridization analysis of the FMRFamide neuropeptide gene in Drosophila. II. Constancy in the cellular pattern of expression during metamorphosis. J Comp Neurol 304:623-638.

Posnett DN, Tam JP. 1989. In: Langone JJ, editor. Multiple antigenic peptide method for producing antipeptide sitespecific antibodies. Methods in Enzymology Vol. 178. New York: Academic Press. p 739-746.

Price DA, Doble KE, Lesser W, Greenberg MJ, Swiderick KM, Lee TD, Lutz EM, Sommerville J, Falconer S, Cottrell GA. 1997. The peptide pQFYRFamide is encoded on the FMRFamide precursor of the snail Helix 
aspersa but does not activate the FMRFamide-gated sodium current. Biol Bull 191:341-351.

Price DA, Greenberg MJ. 1977. Structure of a molluscan cardioexcitatory neuropeptide. Science 197:670-672.

Raabe M. 1989. Recent developments in insect hormones. New York: Plenum Press.

Raffa RB. 1989. The action of FMRFamide (Phe-Met-ArgPhe- $\mathrm{NH}_{2}$ ) and related peptides on mammals. Peptides 9:915-922.

Robb S, Packman LC, Evans PD. 1989. Isolation, primary structure and bioactivity of SchistoFLRF-amide, a FMRF-amide-like neuropeptide from the locust, Schistocerca gregaria. Biochem Biophys Res Commun 160: $850-856$.

Santama N, Benjamin PR, Burke JF. 1995. Alternative RNA splicing generates diversity of neuropeptide expression in the brain of the snail Lymnaea: in situ analysis of mutually exclusive transcripts of the FMRFamide gene. Eur J Neurosci 7:65-76.

Santama N, Li KW, Geraerts WP, Benjamin PR, Burke JF. 1996. Posttranslational processing of the alternative neuropeptide precursor encoded by the FMRFamide gene in the pulmonate snail Lymnaea stagnalis. Eur J Neurosci 8:968-977.

Saunders SE, Kellett E, Bright K, Benjamin PR, Burke JF. 1992. Cell-specific alternative splicing of an FMRFamide gene transcript in the brain. J Neurosci 12:1033-1039.

Schneider LE, O'Brien MA, Taghert PH. 1991. In situ hybridization analysis of the FMRFamide neuropeptide gene in Drosophila. I. Restricted expression in embryonic and larval stages. J Comp Neurol 304:608-622.

Schneider LE, Sun ET, Garland DJ, Taghert PH. 1993. An immunocytochemical study of the FMRFamide neuropeptide gene products in Drosophila. J Comp Neurol 337:446-460.

Schneider LE, Taghert PH. 1988. Isolation and characterization of a Drosophila gene that encodes multiple neuropeptides related to FMRFamide. Proc Natl Acad Sci USA 85:1993-1997.

Schoofs L, Veelaert D, Broeck JV, De Loof A. 1997. Peptides in the locusts, Locusta migratoria and Schistocerca gregaria. Peptides 18:145-156.

Strausfeld NJ. 1976. Atlas of an insect brain. Berlin: Springer.

Strausfeld NJ. 1984. Functional anatomy of the blowfly's visual system. In: Ali AM, editor. Photoreception and vision in invertebrates. New York: Plenum Press. p 483-522.
Trimmer BA. 1985. Serotonin and the control of salivation in the blowfly Calliphora. J Exp Biol 114:307-328.

Umino O, Dowling JE. 1991. Dopamine release from interplexiform cells in the retina: effects of GnRH, FMRFamide, bicuculline, and enkephalin on horizontal cell activity. J Neurosci 11:3034-3046.

Voronezhskaya EE, Elekes K. 1996. Transient and sustained expression of FMRFamide-like immunoreactivity in the developing nervous system of Lymnaea stagnalis (Mollusca, Pulmonata). Cell Mol Neurobiol 16: 661-676.

Wang Z, Orchard I, Lange AB, Chen X. 1995. Mode of action of an inhibitory neuropeptide SchistoFLRFamide on the locust oviduct visceral muscle. Neuropeptides 8:147-155.

Weiss S, Goldberg JI, Chohan KS, Stell WK, Drummond GI, Lukowiak K. 1984. Evidence for FMRF-amide as a neurotransmitter in the gill of Aplysia californica. J Neurosci 4:1994-2000.

White K, Hurteau P, Punsal P. 1986. Neuropeptide-FMRFamide-like immunoreactivity in Drosophila: development and distribution. J Comp Neurol 247:430-438.

Wikgren M, Fagerholm HP. 1993. Neuropeptides in sensory structures of nematodes. Acta Biol Hung 44:133-136.

Witten JL, Truman JW. 1996. Developmental plasticity of neuropeptide expression in motoneurons of the moth, Manduca sexta: steroid hormone regulation. J Neurobiol 29:99-114.

Wurden S, Homberg U. 1995. Immunocytochemical mapping of serotonin and neuropeptides in the accessory medulla of the locust, Schistocerca gregaria. J Comp Neurol 362:305-319.

Xu Y, Cleary LJ, Byrne JH. 1994. Identification and characterization of pleural neurons that inhibit tail sensory neurons and motor neurons in Aplysia: correlation with FMRFamide immunoreactivity. J Neurosci 14:35663577.

Yang H-YT, Fratta W, Majane EA, Costa E. 1985. Isolation, sequencing, synthesis, and pharmacological characterization of two brain neuropeptides that modulate the action of morphine. Proc Natl Acad Sci USA 82:77577761.

Zitnan D, Sauman I, Sehnal F. 1993. Peptidergic innervation and endocrine cells of insect midgut. Arch Insect Biochem Physiol 22:113-132. 